\title{
CHALLENGES IN ASSESSING ECOLOGICAL IMPACTS OF CONSTRUCTION AND DEMOLITION WASTE ON WETLANDS: A CASE STUDY
} \author{
Staunton, J. ${ }^{1,2},{ }^{*}$ - Williams, C.D. ${ }^{3}$ - MC Donnell, R.J. ${ }^{4}$ - Fleming, G.T.A. ${ }^{5}$ - HenRY, T. $^{2}$ -
GORMAlly, M.J. \\ ${ }^{1}$ Applied Ecology Unit, Centre for Environmental Science, School of Natural Sciences, \\ NUI Galway, Ireland. \\ (phone: +353-91-492719; fax: +353-91-494598) \\ ${ }^{2}$ Earth and Ocean Science, School of Natural Sciences, NUI Galway, Ireland. \\ (phone: +353-91-495096) \\ ${ }^{3}$ Behavioural Ecology and Biocontrol Laboratory, Department of Biology, \\ NUI Maynooth, Ireland. \\ (phone: +353-1-7086852) \\ ${ }^{4}$ Department of Entomology, University of California, Riverside CA92521, USA \\ (phone: +1-951-8277256) \\ ${ }^{5}$ Microbiology, School of Natural Sciences, NUI Galway, Ireland. \\ (phone: +353-91-493562) \\ *Corresponding author: \\ Email:johns86@hotmail.com \\ (Received $21^{\text {st }}$ Nov 2013 ; accepted $22^{\text {nd }}$ July 2014)
}

\begin{abstract}
Although wetlands are of ecological and economic importance, they continue to be lost to anthropogenic activities such as infilling. The impacts of wetland infilling with construction and demolition (C\&D) waste on wetland plant and dipteran (Insecta: Diptera) communities were examined. Areas of wetland infilled with C\&D waste compared to non-infilled areas had: a) higher soil $\mathrm{pH}$ and lower soil moisture / organic content; b) a relatively higher percentage of ruderal plant communities; c) relatively fewer dipteran families that were wetland specialist, gall-forming, parasitic and haematophagous; d) relatively lower abundances and species richness of marsh flies (Diptera: Sciomyzidae). Challenges encountered during this study included locating C\&D waste sites; obtaining permission from landowners to undertake this study; frequent damage and theft of equipment due to human interference, machinery and infilling activity. Given the current paucity of data regarding the ecological impacts of infilling with C\&D waste on wetlands and the considerable challenges with undertaking such studies, we make recommendations for appropriate site selection and monitoring at C\&D waste infill sites.
\end{abstract}

Keywords: Construction \& Demolition waste; wetlands; ecological impacts; Diptera; surveying challenges

\section{Introduction}

\section{Wetlands}

Wetlands are considered as some of the most ecologically and economically important habitats worldwide. Covering between seven and ten million $\mathrm{km}^{2}$ globally, they provide many important ecosystem services (Costanza et al., 1997; Keddy, 2000; Lehner and Döll, 2004), including the provision of essential habitats for wetland plant 
and invertebrate communities, water filtration and flood control. However, wetlands have been and continue to be lost at significant rates: two-thirds of European wetlands were lost during the $20^{\text {th }}$ century due to anthropogenic activities (EC, 1995) such as draining, dredging and infilling (Mitsch and Gosselink, 2007) with agriculture being one of the main driving forces behind the loss (Chen et al. 2012). This is not surprising given that wetlands are frequently perceived as land with no direct economic benefit to the landowner. Infilling with construction and demolition waste (Poon, 2001; Shen et al., 2004) is, therefore, seen as a means of creating improved agricultural grassland by covering the infill with topsoil or developing dry, elevated sites for building purposes.

\section{Construction and demolition waste}

Construction and demolition (C\&D) waste can be described as waste that is produced as a result of the construction, demolition or renovation of structures (Shen et al., 2004; USEPA, 2009). It is composed of a mix of wastes from building sites, including concrete, wood and asphalt (EPA, 2009; Fischer and Werge, 2009; Poon et al., 2001; Williams, 1998). Although approximately 870 million tonnes (32.9\% of total waste) of C\&D waste were produced in EU countries in 2008 (Eurostat, 2011), detailed information regarding the disposal of the waste is not currently available (European Commission DG ENV, 2011) given that EU countries frequently categorise infilling as C\&D waste recycling. Nevertheless, some EU countries (Spain, Hungary and Ireland) have documented problems with illegal disposal of C\&D waste (European Commission DG ENV, 2011; EPA staff member, Pers. Comm.) in unregulated fill sites.

Information on the regulation of C\&D waste infill in Ireland is presented in Table 1. Prior to 2001, municipal landfills were the only legal sites at which C\&D waste could be placed. However, with the waste being viewed as mainly inert, it was often used as unregulated fill material (EPA, 1996; EPA staff member, Pers. Comm.). Post-2001 Waste Permits (WP) were obtained for many of these unregulated sites, usually without any ecological assessment, so that infilling could continue. The more recently introduced Certificates of Registration (COR) which require submission of biodiversity details of the site, give no indication of the level of ecological detail required for the granting of the permit. Given this situation, the loss, due to C\&D infilling, of unprotected Irish wetlands and their associated biota is likely to be still taking place.

With the exception of a single publication by Gabrey (1997) which found that C\&D waste had no significant impacts on bird populations in the USA (in the context of birds as hazards to nearby airports), the ecological impacts of infilling wetlands with C\&D waste have been poorly studied. Wetland sites infilled with C\&D waste are, at best, challenging sites to complete ecological investigations, for a number of reasons. Landowners may refuse requests to undertake site surveys (noted by Krause et al., 2013 when undertaking stream investigations) due to the possibility, in this case, of an ecological surveyor discovering hazardous, non-C\&D waste material. On the other hand, C\&D waste sites frequently have open access and are subject to constant disturbance, not only from machinery dumping and spreading the $C \& D$ waste but from illegal fly-tipping activities. While the authors quickly became aware of these challenges early in this study, we nevertheless persisted with our investigations in the belief that quantitative data, in the form of a case study, would go at least some way in highlighting the ecological effects of infilling wetlands with C\&D waste, given the paucity of knowledge in this field. These data can bring to light potential ecological 
impacts on wetlands of C\&D waste with a view to informing policy changes for future site selection and monitoring. With this in mind, we concentrated on wetland biological groups such as plants which are sensitive to chemical changes in their environment (LaPaix et al.2009; Pardo et al., 2011) and Diptera (families and morphospecies), shown to be influenced by vegetation structure (Hughes et al., 2000; King \& Brazner, 1999; Whiles and Goldowitz, 2001). In particular, we identified marsh flies (Diptera: Sciomyzidae), to species level since they have been shown to reflect a range of wetland conditions (Murphy et al., 2012; Speight, 1986; Williams et al., 2009, 2010). While plants are frequently used in isolation to assess habitats, we included invertebrate groups in this study given that, apart from charismatic invertebrate species such as butterflies, policy makers can often be unaware of problems associated with general invertebrate conservation (Cardoso et al., 2011).

Table 1. Regulations relating to Construction and Demolition (C\&D) Waste infilling in the Republic of Ireland. ta- $1=$ tonnes per annum. $n a=$ not applicable. EIA $=$ Environmental Impact Assessment. AA = Appropriate Assessment.

\begin{tabular}{|c|c|c|c|}
\hline & $\begin{array}{l}\text { C\&D waste disposal } \\
\text { permits }^{a, b, c, d, e, f}\end{array}$ & Outcomes $^{\text {a, b,c }}$ & Ecological survey details ${ }^{b, c, d, e, f}$ \\
\hline $\begin{array}{l}\text { Pre } \\
2001\end{array}$ & $\begin{array}{l}\text { No C\&D specific } \\
\text { disposal sites. C\&D } \\
\text { waste was directed to } \\
\text { municipal landfills }\end{array}$ & $\begin{array}{l}\text { C\&D waste often used } \\
\text { as unregulated fill } \\
\text { material. Many of these } \\
\text { sites granted WPs post } \\
2001 \text { to continue } \\
\text { infilling }\end{array}$ & na \\
\hline 2001 - & $\begin{array}{l}<5,000 \text { ta }^{-1}: \text { Waste } \\
\text { permits (WP) granted } \\
\text { by local authority }\end{array}$ & $\begin{array}{l}\text { Most inert C\&D waste } \\
\text { was disposed on WP } \\
\text { sites }\end{array}$ & $\begin{array}{l}\text { Ecological information not essential - } \\
\text { Environmental survey (no details given) } \\
\text { decided on a case-by-case basis in } \\
\text { situations where pollution is likely, or } \\
\text { site is near/in Natura } 2000 \text { site }\end{array}$ \\
\hline 2008 & $\begin{array}{l}>5,000 \mathrm{ta}^{-1}: \text { Waste } \\
\text { License granted by } \\
\text { EPA }\end{array}$ & $\begin{array}{l}\text { Few Waste Licenses } \\
\text { granted with result that } \\
\text { most inert C\&D waste } \\
\text { was disposed on WP } \\
\text { sites }\end{array}$ & $\begin{array}{l}\text { Environmental survey (EIA) required } \\
\text { for waste license. (See EPA Advice } \\
\text { Notes on Current Practice }{ }^{g} \text { ) }\end{array}$ \\
\hline \multirow[t]{2}{*}{$\begin{array}{l}2008- \\
\text { present }\end{array}$} & $\begin{array}{l}<10,000 \text { ta }^{-1}: \\
\text { Certificate of } \\
\text { Registration (COR) } \\
\text { granted by local } \\
\text { authority } \\
10,000-50,000 \text { ta }^{-1}: \\
\text { Waste Facility } \\
\text { Permit (WFP) } \\
\text { granted by local } \\
\text { authority }\end{array}$ & $\begin{array}{l}\text { Most inert C\&D waste } \\
\text { disposed on COR or } \\
\text { WFP sites }\end{array}$ & $\begin{array}{l}\text { Application requires details of } \\
\text { biodiversity on site. No information on } \\
\text { minimum level of ecological detail } \\
\text { required. } \\
\text { EIA required if pollution is likely - this } \\
\text { is decided on a case-by-case basis OR if } \\
\text { waste }>25,000 \text { tonnes. } \\
\text { AA }^{\text {h }} \text { required if there are potential } \\
\text { impacts on NATURA } 2000 \text { site }\end{array}$ \\
\hline & $\begin{array}{l}>50,000 \mathrm{ta}^{-1}: \text { Waste } \\
\text { License granted by } \\
\text { EPA }\end{array}$ & $\begin{array}{l}\text { Most inert C\&D waste } \\
\text { disposed on COR or } \\
\text { WFP sites }\end{array}$ & $\begin{array}{l}\text { EIA required. } \mathrm{AA}^{\mathrm{h}} \text { required if there are } \\
\text { potential impacts on NATURA } 2000 \\
\text { site }\end{array}$ \\
\hline
\end{tabular}


This study presents a description of nine wetland sites which have been affected by the infilling of C\&D waste. The objectives of the study are to compare, for the first time, plant and dipteran communities on the C\&D infilled and non-infilled portions of wetlands. Our hypothesis is that plant and dipteran community composition will be significantly different on C\&D infilled and non-infilled portions of wetlands. In addition, we identify problems currently associated with ecological site investigations at C\&D infill sites with a view to developing recommendations for appropriate site selection and monitoring.

\section{Methods}

\section{Study area}

Nine sites (Table 2), located in County Galway (Fig. 1) in the west of Ireland were investigated for this study. Eleven sites were originally selected for the present study. However, two of these sites had to be abandoned within weeks of starting due to repeated vandalism and theft of invertebrate sampling equipment. Sites were chosen from all County Galway sites for which permits were held for the disposal of C\&D waste. They were selected on the basis of proximity to each other so that aerial invertebrate samples could be collected from all sites on the same day, thereby reducing the influence of weather conditions on invertebrate catches. Most sites were chosen in areas to the north of Galway city where there is a concentration of wetlands. Sites were selected from those wetlands which were partly infilled with C\&D waste to facilitate comparisons between the infilled and non-infilled portions of the wetlands. Habitat classification was carried out on the selected sites following Fossitt (2000).

The nine sites (Fig. 1; Table 2) consisted of two (WG1 and WG2) wet grassland sites ( soil $\mathrm{pH}>7$ ), two (SW1 and SW2) reed \& large sedge swamp sites (soil $\mathrm{pH}>7$ ) and five $(\mathrm{CB} 1-\mathrm{CB} 5)$ cutover raised bog sites (soil $\mathrm{pH}<7$ ). Total wetland sizes ranged from 9ha to 169 ha (estimated from aerial photography). One site (WG1) was situated within an EU designated Special Area of Conservation (SAC) on the River Clare. All sites had already been partly infilled with C\&D waste when this study began, with varying levels of infilling activity being carried out during the study period.

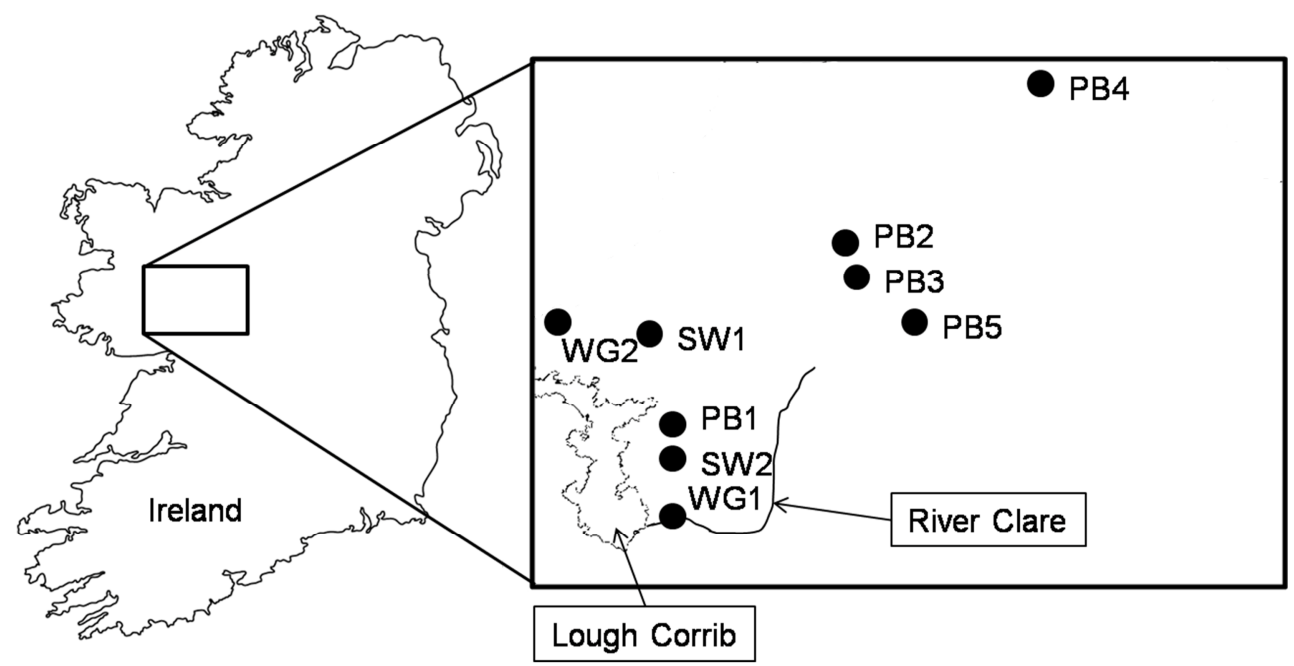

Figure 1. Location of wetland study sites within County Galway, Ireland 


\section{Sampling methods}

Diptera were sampled in 2009 and 2010 while vegetation surveys and soil sampling were undertaken in 2010. However, due to infilling activity and discontinuation of access permission to sites CB5 and SW2 respectively at the end of 2009, vegetation surveys and soil sampling took place on seven sites only. Vegetation surveys were carried out on sites WG1, WG2, SW1 and CB1-CB4 in August 2010. Sampling in the wetland using three $0.5 \mathrm{~m} \times 0.5 \mathrm{~m}$ quadrats (Bullock, 2006), $5 \mathrm{~m}$ apart, was restricted to $5 \mathrm{~m}$ from the edge of the infill and, in the infill, to $5 \mathrm{~m}$ from the edge of the wetland. This sampling strategy was limited by the size of the smallest site with other sites being sampled in the same manner for comparative purposes. In addition, depth of water became greater in some of the wetlands with distance from the infill and safety considerations prevented sampling in these areas. Nevertheless, given the abrupt changes in plant communities that can be seen at the interface between the infill and wetland (Fig. 2), the vegetation data recorded gives a good indication of differences in plant communities at the infill and wetland interface.

All plant species within each quadrat were identified using Rose and O'Reilly (2006) and Webb et al. (1996). Percentage cover of each plant species, bryophytes (bryophytes were not identified to species level, but were dealt with as a group), dead vegetation and bare ground were recorded. Within each quadrat, four measurements were taken randomly with a ruler for both vegetation height (maximum height from ground of resting vegetation) and vegetation length (length of longest plant when stretched out), as measurements of structural complexity for use in data analysis (Williams, 2010). Ellenberg indices (Hill et al., 1999), as corrected for use in the British Isles by Hill et al. (2000), were used as additional surrogate environmental variables, and were calculated following Williams et al. (2011). Ellenberg indices are based on the plant community data and can be used to indicate soil parameters (moisture, $\mathrm{pH}$ and nitrogen content) and light intensity. Ellenberg values (moisture and $\mathrm{pH}$ ) were also compared with measured field soil parameters.

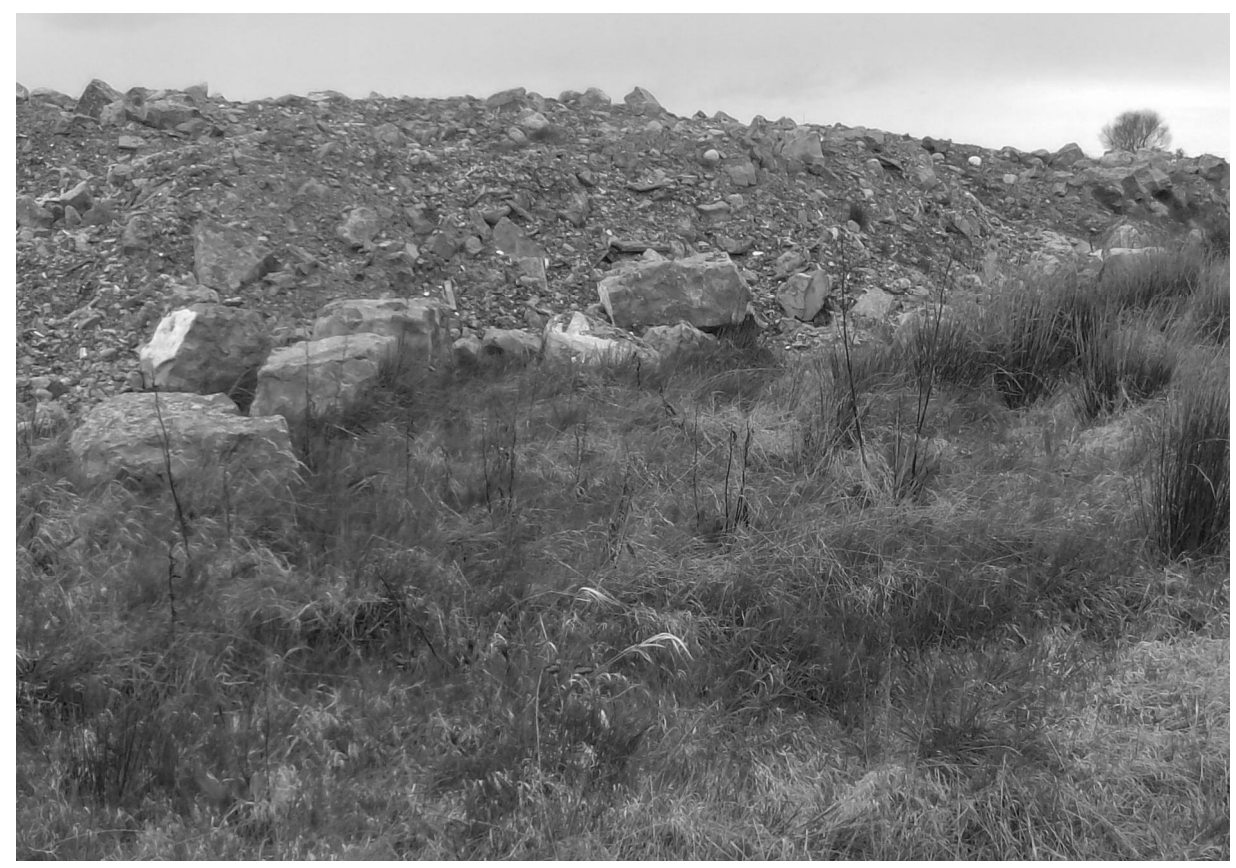

Figure 2. Example of interface between infill and wetland 
Using a Dutch auger (Eijkelkamp), soil samples at each quadrat (ca. two kilograms) were taken in 2012 to a depth of $20 \mathrm{~cm}$. C\&D waste which was frequently compacted by heavy machinery was difficult to penetrate preventing the extraction of samples at lower depths. Moisture content (expressed as a percentage of the wet weight), mass loss-onignition (expressed as a percentage of the dry weight) and $\mathrm{pH}$ (using soil suspensions) were determined according to British Standards (BSI, 1990). Results from individual samples were averaged (mean if normal distribution obtained, otherwise median) for the infill and for the wetland zones of each site for comparison.

Aerial invertebrates (Diptera) were collected using pan traps (Southwood, 1978) at all nine sites in 2009 and from the remaining seven sites in 2010. All sciomyzids were removed and identified from these samples. In addition, aerial invertebrates collected in 2009 were identified to morphospecies level for those seven sites in which plant surveys were undertaken in 2010 to allow comparison of the plant and aerial invertebrate data. Each pan trap consisted of a white plastic container $(20 \mathrm{~cm}$ diameter $\times 10 \mathrm{~cm}$ high) placed within a similar container fixed to a wooden post set at $50 \mathrm{~cm}$ (allowing for flood events) above ground level (Southwood 1978; Campbell and Hanula, 2007). One pan trap was placed in the centre of each vegetation quadrat. While it could be argued that some dipteran species could move between infill and wetland trap areas, any differences in data for dipteran community composition are likely to be real differences reflecting the nature of the habitats. A $25 \%$ solution of ethylene glycol (preservative) was added to the pan trap (filled to two centimetres from rim) in addition to a small amount of Ecover $^{\circledR}$ washing up liquid, which was used as a surfactant. The traps were emptied weekly (July 14 to October 13 in 2009; May 6 to September 30 in 2010) and trapped invertebrates were collected by straining the trap contents through a fine nylon mesh $(0.5 \mathrm{~mm})$. All samples were then preserved in a $70 \%$ ethanol solution. Sciomyzidae were identified to species level (Rozkošný, 1984, 1987) for all dates, and all dipteran individuals were identified to family (Oosterbroek, 2006; Unwin, 1981) for three sampling dates in 2009 (14 July; 1 September; 13 October). Taxonomic minimalism reduces time spent on species identification, allowing more samples to be analysed (Beattie and Oliver 1994), while still being a useful method to assess biodiversity (Rivers-Moore and Samways, 1996). Groups with different morphological features were identified within dipteran families and treated as separate morphospecies (Beattie and Oliver, 1994). Adult sciomyzids were identified to species level since they are known to remain close to where they eclose and therefore, reflect different types of wetland conditions (Williams et al., 2010).

Aerial invertebrates were also sampled at one site (WG2) using a sweep net $(50 \mathrm{~cm}$ diameter x $67 \mathrm{~cm}$ bag depth and $30.5 \mathrm{~cm}$ handle length)(Williams et al., 2009) every two weeks in $2010\left(19^{\text {th }}\right.$ May to $22^{\text {nd }}$ September $)$ allowing comparison of catches caught by sweep-netting with the pan trap method. Eight parallel sweep paths (ten metres long with a two metre buffer zone between each) were marked out using bamboo canes on both the wetland and the infill. Vegetation to the east of each path was swept in the standard figure of eight motion (ca. $1 \mathrm{~m}$ wide), and this was carried out by the same person using a consistent walking pace and sweeping speed. The invertebrates in the sweep net were euthanized for each sweep path in the field (with each sweep path being a separate sample) by placing in a kilner jar $(12 \mathrm{~cm}$ diameter $\mathrm{x} 30 \mathrm{~cm})$ with ethyl acetate (99.5\%). Samples were preserved in $70 \%$ ethanol and sciomyzids were identified to species level (Rozkošný, 1984, 1987). Environmental variables measured at the time of sampling were vegetation height, length of outstretched vegetation (both measured 
beside each sweep path), wind speed, humidity (Skywatch ${ }^{\circledR}$ Atmos by JD Industries), light intensity (Hanna Lux meter HI97500) and nebulosity (visual percentage estimate). Uneven surface topography prevented sweep netting at the other sites.

\section{Statistical analysis}

Various statistical procedures were carried out on the collected data to assess if there was a significant difference between the biota of the of wetland area infilled with C\&D waste compared to non-infilled wetland area. Multi-Response Permutation-Procedure (MRPP) was used for observing the strength of grouping variables (habitat type and site) for multivariate datasets (Meilke and Berry, 2001). Non-metric multi-dimensional scaling (NMS) ordinations which do not assume multivariate normality were used to compare plant and dipteran communities of the wetlands and C\&D waste infill (Kenkel and Orloci, 1986). Indicator Species Analysis, a method for observing the association of a species with a particular grouping variable, in this case, habitat (Dufrêne and Legendre, 1997), was also undertaken. Shannon's entropy is used (instead of Shannon's diversity index) as entropy has been shown to be more useful, giving a value for the uncertainty in the data, rather than true diversity (Jost, 2006). Minitab ${ }^{\circledR}$ Statistical Software (version 16) was used for univariate statistical analysis, and PC-ORD (version 6) was used for multivariate analyses (McCune and Grace, 2002; McCune and Mefford, 1999).

\section{Results}

\section{Soils and plant communities}

Overall there were significant differences found between the soil parameters and plant communities of $C \& D$ infill and wetland. When all wetland sites were combined for analysis, mean soil $\mathrm{pH}$ was significantly $(\mathrm{t}=5.71, P<0.05)$ greater on the infill (7.94) than the wetlands (6.41). In addition, median percentage soil moisture content (Table 2) was significantly $(\mathrm{T}<0.1, P<0.05)$ lower on the infill $(15.35 \%)$ than in the wetland $(80.69 \%)$ as was $(\mathrm{t}=11.34, P<0.05)$ mean percentage soil mass loss-on-ignition $(5.03 \%$ on infill and $70.95 \%$ on wetland). Although the cutover raised bog wetlands were all acidic $(\mathrm{pH}<7)$ with the remaining wetland habitats being alkaline $(\mathrm{pH}>7)$, nevertheless, for each site studied, the $\mathrm{pH}$ of the C\&D waste substrate was significantly $(P<0.05)$ greater than the median $\mathrm{pH}$ of the original wetland (Table 2).

A total of 94 plant species were recorded at the seven sites in 2010 ( $n=42$ quadrats), with median plant species richness and Shannon's entropy being significantly $(P<0.05)$ higher on the infill than on wetlands regardless of wetland type (Table 3). However, there was no significant difference $(P>0.05)$ in plant species evenness between infill and wetland. Following separation of sites (according to wetland soil analysis) into acidic $(\mathrm{pH}<7)$ or alkaline $(\mathrm{pH} \geq 7)$ wetlands, the plant data show that variance in plant species composition that was attributable to habitat status (i.e. wetland versus C\&D waste) was slightly higher on acidic sites (15\% of variance) than on alkaline sites (14\% of variance), based on MRPP (Table 4). Table 2 shows the most dominant plant species for each site (wetland and C\&D waste infill). Plant indicator species analysis was performed on the acidic and alkaline sites separately using the Monte-Carlo test of 
Table 2. Brief description of the nine wetland and infill study sites in Co. Galway, Ireland. Site code explanation: $W G=$ Wet Grassland, $S W=$ Swamp, $C B=$ Cutover Raised Bog, $n d=$ no data.

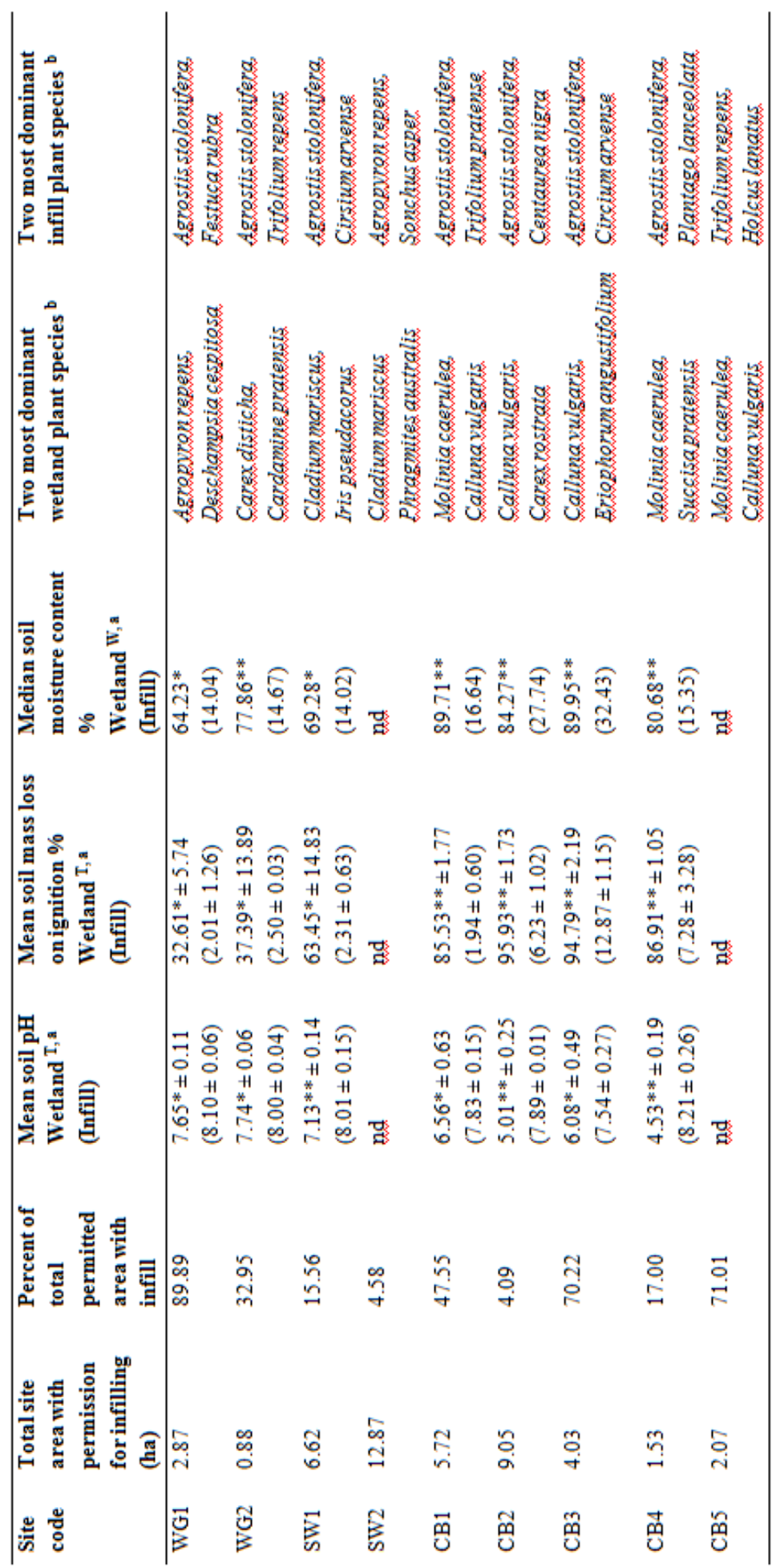

* Significant difference between infill and wetland data with $(P<0.05)$ and $* *(P<0.005) .{ }^{\text {w }}$ Wilcoxon signed rank test used. ${ }^{\mathrm{T}}$ paired t-test used. ${ }^{\mathrm{a}}$ Mean \pm standard deviation calculated from three samples of soil from both infill and wetland areas on each site. ${ }^{b}$ Most dominant species based on percentage cover. 
Table 3. Species richness, species evenness and Shannon's entropy of all sites (only WG2 for sweep net data) for vegetation, Sciomyzidae and dipteran families and morphospecies. na $=$ not applicable (due to zero collections).

\begin{tabular}{|c|c|c|c|}
\hline Dataset & $\begin{array}{l}\text { Median species richness } \\
\text { wetland }^{\mathrm{w}, \mathrm{a}} \text { (infill) }\end{array}$ & $\begin{array}{l}\text { Median species } \\
\text { evenness } \\
\text { wetland }^{\text {w, a }} \text { (infill) } \\
\end{array}$ & $\begin{array}{l}\text { Median species } \\
\text { entropy } \\
\text { wetland }{ }^{\mathrm{w}, \mathrm{a}} \text { (infill) }\end{array}$ \\
\hline 2010 Vegetation & $\begin{array}{l}10.00 \pm 4.57^{* *} \\
(17.00 \pm 5.54)\end{array}$ & $\begin{array}{l}0.74 \pm 0.14 \\
(0.75 \pm 0.08)\end{array}$ & $\begin{array}{l}1.66 \pm 0.56^{* *} \\
(2.24 \pm 0.14)\end{array}$ \\
\hline $\begin{array}{l}2009 \text { (pan trap) } \\
\text { Sciomyzidae }\end{array}$ & $\begin{array}{l}2.00 \pm 1.28 \\
(1.00 \pm 1.64)\end{array}$ & $\begin{array}{l}0.45 \pm 0.43 \\
(0.00 \pm 0.45)\end{array}$ & $\begin{array}{l}0.56 \pm 0.40 \\
(0.00 \pm 0.53)\end{array}$ \\
\hline $\begin{array}{l}2010 \text { (pan trap) } \\
\text { Sciomyzidae }\end{array}$ & $\begin{array}{l}1.00 \pm 0.39 \\
(\mathrm{na})\end{array}$ & $\begin{array}{l}0.00 \pm 0.37 \\
(\mathrm{na})\end{array}$ & $\begin{array}{l}0.00 \pm 0.26 \\
(\mathrm{na})\end{array}$ \\
\hline $\begin{array}{l}2010 \text { (sweep net) } \\
\text { Sciomyzidae }\end{array}$ & $\begin{array}{l}4.00 \pm 1.30^{*} \\
(0.00 \pm 0.92)\end{array}$ & $\begin{array}{l}0.79 \pm 0.09^{*} \\
(0.00 \pm 0.46)\end{array}$ & $\begin{array}{l}0.63 \pm 0.05^{*} \\
0.00 \pm 0.28\end{array}$ \\
\hline $\begin{array}{l}2009 \text { Dipteran } \\
\text { family }\end{array}$ & $\begin{array}{l}24.00 \pm 3.45 \\
(25.00 \pm 4.38)\end{array}$ & $\begin{array}{l}0.81 \pm 0.07 \\
(0.77 \pm 0.08)\end{array}$ & $\begin{array}{l}2.61 \pm 0.28 \\
(2.44 \pm 0.28)\end{array}$ \\
\hline $\begin{array}{l}2009 \text { Dipteran } \\
\text { morphospecies }\end{array}$ & $\begin{array}{l}48.00 \pm 12.08 \\
(44.00 \pm 12.07)\end{array}$ & $\begin{array}{l}0.81 \pm 0.07 \\
(0.77 \pm 0.09)\end{array}$ & $\begin{array}{l}3.26 \pm 0.40 \\
(2.91 \pm 0.42)\end{array}$ \\
\hline
\end{tabular}

* Significant difference between infill and wetland data with $(P<0.05)$ and $* *(P<0.005)$. ${ }^{\text {w }}$ Wilcoxon signed rank test used. ${ }^{a}$ Median \pm standard deviation calculated from all sites.

Table 4. Multi-Response Permutation-Procedure (MRPP) for vegetation, Sciomyzidae and dipteran families and morphospecies (Distance measure: Sørensen). Chance corrected within group agreement is a measure of within group homogeneity and P-values were assessed by permutation. Alkaline $=$ sites with wetland soil $p H \geq 7 ;$ Acidic $=$ sites with wetland soil $\mathrm{pH}<7$. na $=$ not applicable (analysis could not be performed as all sciomyzids for 2010 were captured on wetland area).

\begin{tabular}{l|l|l|l}
\hline Dataset & Grouping variable & $\begin{array}{l}\text { Chance-corrected } \\
\text { within-group agreement } \\
(\boldsymbol{A})\end{array}$ & $\boldsymbol{P}$ \\
\hline 2010 Vegetation & Infill v Wetland (alkaline) & 0.14 & $2 \times 10^{-5}$ \\
& Infill v Wetland (acidic) & 0.15 & $3 \times 10^{-6}$ \\
& Between site (alkaline) & 0.19 & $7 \times 10^{-5}$ \\
& Between site (acidic) & 0.07 & 0.01 \\
2009 Dipteran & Infill v Wetland (alkaline) & 0.04 & $\mathrm{a}$ \\
Family & Infill v Wetland (acidic) & 0.06 & $3 \times 10^{-4}$ \\
& Between site (alkaline) & 0.32 & $5 \times 10^{-8}$ \\
& Between site (acidic) & 0.14 & $3 \times 10^{-6}$ \\
2009 Dipteran & Infill v Wetland & 0.04 & $2 \times 10^{-5}$ \\
Morphospecies & Between site & 0.21 & $10^{-8}$ \\
2009 sciomyzid & Infill v Wetland & 0.07 & $5 \times 10^{-3}$ \\
pan traps & Between site & 0.11 & 0.03 \\
2010 sciomyzid & Infill v Wetland & na & na \\
pan traps & Between site & 0.02 & a \\
& & 0.14 & $5 \times 10^{-3}$ \\
2010 sciomyzid & Infill v wetland & \\
sweep net & & & \\
\hline
\end{tabular}

${ }^{\text {a }}$ not significant at $P>$ 
significance (Table 5). Eleven plant species were found to be significant indicators of C\&D waste on acidic sites, and six on alkaline sites, with Agrostis stolonifera L. having the highest percentage of perfect indication on both. Of the six indicator plant species of C\&D waste on alkaline sites, four (A. stolonifera, Cerastium fontanum Baugm, Lolium perenne L. and Ranunculus repens L.) were also listed as indicators of C\&D waste on acid sites (Table 5). Four plant species (Calluna vulgaris (L.) Hull, Erica tetralix L., Molinia caerulea (L.) Moench and Potentilla erecta (L.) Rauschel) were significant indicators of wetland on acidic sites, with M. caerulea having the highest percentage of perfect indication (Table 5). Alkaline sites, which consisted of more variable wetland types, were without significant wetland indicator species.

Non-metric multi-dimensional scaling (NMS) ordinations after McCune and Grace (2002) were performed with the plant data (Fig. 3a), with soil moisture, loss-on-ignition and $\mathrm{pH}$ included as vectors, resulting in a 3-dimensional solution. The plant community ordination (Fig. 4) showed the C\&D waste infill communities to be tightly clustered indicating a high similarity between these sites regardless of the type of wetland which had been infilled with C\&D waste. The wetland points, however, were more dispersed suggesting a higher variation between wetland plant communities. For the plant community data, axis 1 was most strongly correlated $\left(r^{2}=.446\right)$ with Ellenberg moisture indicating the importance of moisture in determining plant community composition (Table 7).

Table 5. Indicator species analysis results for vegetation data from 2010 ( $n=42$ quadrats). (Monte-Carlo randomised test, 4999 permutations). IV = percent perfect indication.

\begin{tabular}{|c|c|c|c|c|}
\hline Max. Group & & Indicator species & IV & $\begin{array}{l}P(4,999 \\
\text { permutations })\end{array}$ \\
\hline \multirow[t]{2}{*}{$\begin{array}{l}\text { Acidic sites } \\
\text { only }\end{array}$} & Infill & $\begin{array}{l}\text { Agrostis stolonifera } \\
\text { Cerastium fontanum } \\
\text { Circium arvense } \\
\text { Holcus lanatus } \\
\text { Lathyrus pratensis } \\
\text { Lolium perenne } \\
\text { Plantago lanceolata } \\
\text { Polygonum amphibium } \\
\text { Ranunculus repens } \\
\text { Taraxacum officinalis } \\
\text { Trifolium repens }\end{array}$ & $\begin{array}{l}99.7 \\
69.6 \\
70.0 \\
86.1 \\
41.7 \\
66.7 \\
54.8 \\
41.7 \\
73.8 \\
41.7 \\
66.7\end{array}$ & $\begin{array}{l}2 \times 10^{-4} \\
0.031 \\
0.002 \\
2 \times 10^{-4} \\
0.037 \\
0.008 \\
0.019 \\
0.037 \\
6 \times 10^{-4} \\
0.036 \\
0.002\end{array}$ \\
\hline & Wetland & $\begin{array}{l}\text { Calluna vulgaris } \\
\text { Erica tetralix } \\
\text { Molinia caerulea } \\
\text { Potentilla erecta }\end{array}$ & $\begin{array}{l}58.3 \\
38.1 \\
74.5 \\
71.2\end{array}$ & $\begin{array}{l}0.006 \\
0.002 \\
4 \times 10^{-4} \\
6 \times 10^{-4}\end{array}$ \\
\hline \multirow[t]{2}{*}{$\begin{array}{l}\text { Alkaline sites } \\
\text { only }\end{array}$} & Infill & $\begin{array}{l}\text { Agrostis stolonifera } \\
\text { Bryophytes } \\
\text { Cerastium fontanum } \\
\text { Festuca rubra } \\
\text { Lolium perenne } \\
\text { Ranunculus repens }\end{array}$ & $\begin{array}{l}99.8 \\
83.8 \\
55.6 \\
99.4 \\
66.7 \\
88.9\end{array}$ & $\begin{array}{l}4 \times 10^{-4} \\
0.001 \\
0.031 \\
4 \times 10^{-4} \\
0.008 \\
6 \times 10^{-4}\end{array}$ \\
\hline & Wetland & No indicators with $P<0.05$ & - & - \\
\hline
\end{tabular}



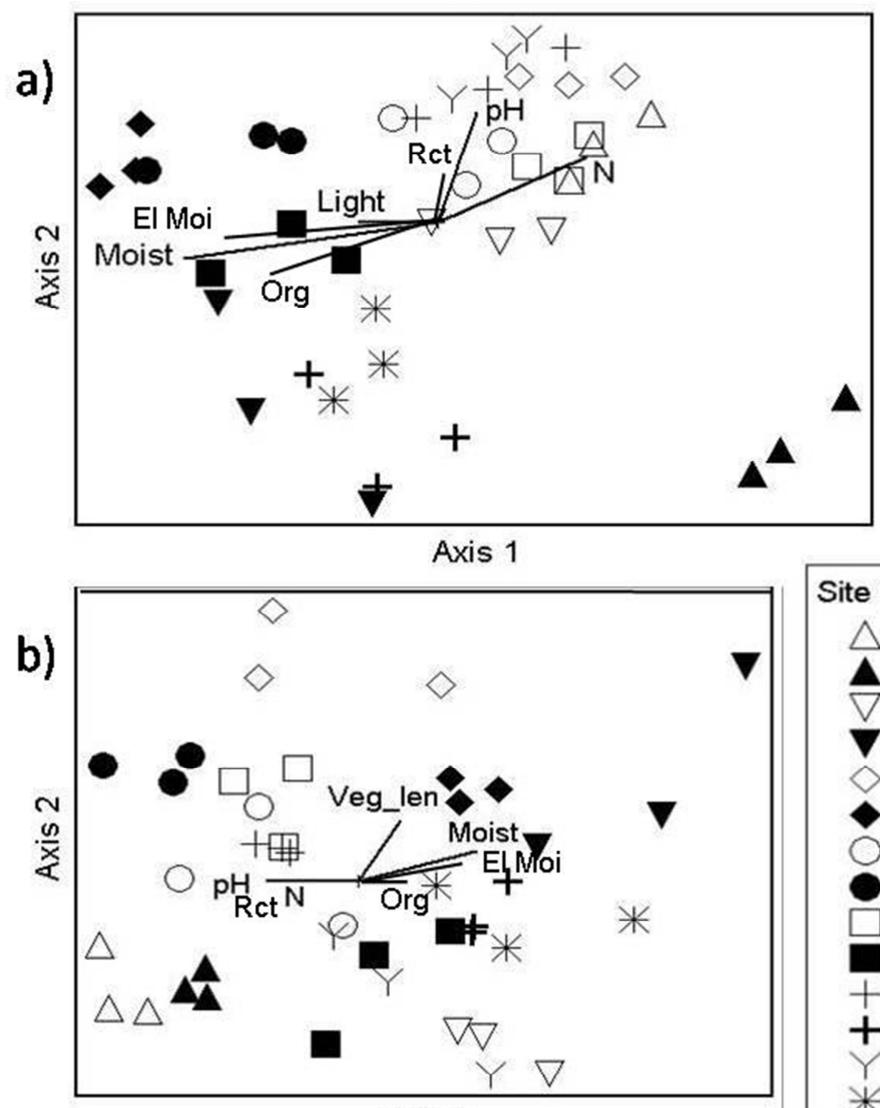

Site (infill/wetland)
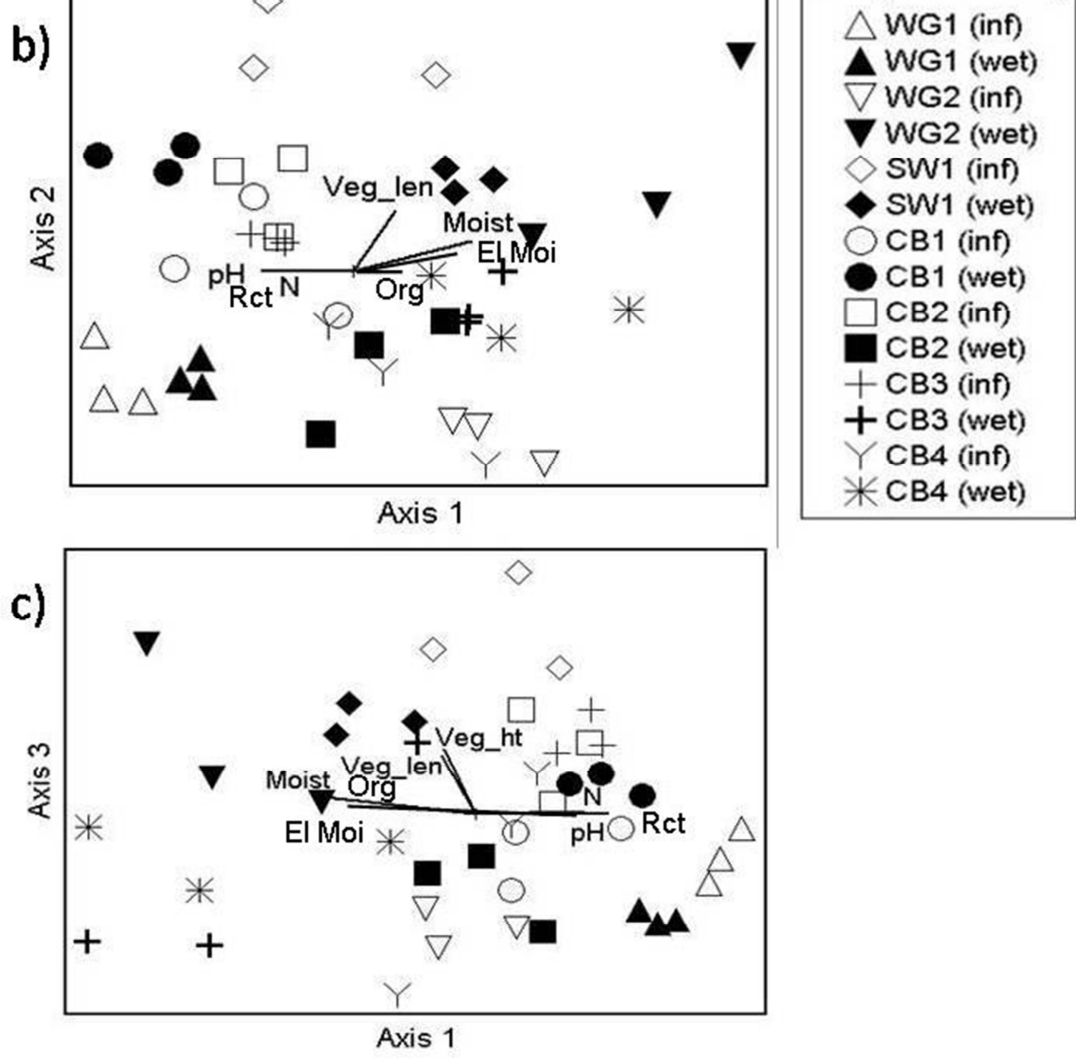

Figure 3. Non-metric multi-dimensional scaling (NMS) ordinations of sites in plant species space (a), dipteran family space (b) and dipteran morphospecies space (c). a) shows the 2010 plant community data (48 iterations, stress of 12.316). b) shows the 2009 dipteran family data from pan traps (45 iterations, final stress of 11.584). c) shows the 2009 dipteran morphospecies data from pan traps (47 iterations, final stress of 11.711). Distance measure: Sørensen, random starting configuration, three-dimensional solutions with orthogonality of $100 \%$, final instability of $<0.001$. Coefficients of determination for the correlations between ordination distances and distances in the original n-dimensional space were: a): axis $1=0.287$, axis $2=0.288$, axis $3=$

0.154 , b) axis $1=0.516$, axis $2=0.224$ and axis $3=0.055$ and c) axis $1=0.565$, axis $2=$ 0.117 and axis $3=0.131$. Environmental variables are overlaid as vectors. Light $=$ Ellenberg light, $N=$ Ellenberg soil nitrogen, El Moi = Ellenberg soil moisture, Rct $=$ Ellenberg soil reaction $(\mathrm{pH})$, Veg_len $=$ vegetation length, Veg_ht $=$ vegetation height, Moist $=$ percentage soil moisture, $\mathrm{pH}=$ soil $\mathrm{pH}$, Org = percentage soil mass loss-on-ignition (organic content), wet $=$ wetland and inf $=$ infill. 


\section{Dipteran communities}

Forty-four dipteran families were identified from a total of 10,688 individuals collected using pan traps on three sampling dates in 2009 (14 July; 1 September; 13 October) across seven sites (CB1 - CB4, SW1, WG1 \& WG2). There was no significant difference in median morphospecies richness, evenness or Shannon's entropy for any dipteran families identified (Table 3). Following separation by wetland soil $\mathrm{pH}$ (as with plant data above), site-specific differences accounted for $32 \%$ of variation in dipteran family composition for alkaline sites, and $14 \%$ for acidic sites whereas habitat status (infill $\mathrm{v}$ wetland) accounted for only $4 \%$ and $6 \%$ of the variance, respectively based on MRPP (Table 4). Table 6 shows the significant indicator dipteran families for C\&D waste (six families) and wetlands (four families). The families Chloropidae and Phoridae had the highest percentage of perfect indication for infill at $73.7 \%$ and $66.8 \%$, respectively. For wetlands, the two best indicators were Culicidae and Chironomidae, with values of $71.8 \%$ and $69.5 \%$, respectively. The Family Sciomyzidae was found to have a percentage of perfect indication of $26.1 \%(P=0.083)$ as indicators of wetlands. This low percentage (and higher $P$ value) is likely due to low abundances, especially on the cutover raised bog sites. Similar to the plant indicator species, there was no overlap in indicator morphospecies or sciomyzids between infill and wetlands.

Table 6. Indicator species analysis results pan trap dipteran family data from $2009(n=42$ pans), pan trap sciomyzid data from 2009 ( $n=54$ pans) and 2010 ( $n=42$ pans), and sweep net sciomyzid data ( $n=16$ paths) for 2010 (Monte-Carlo randomised test, 4999 permutations). IV= percent perfect indication.

\begin{tabular}{|c|c|c|c|c|c|}
\hline Dataset & $\begin{array}{l}\text { Indicator species / } \\
\text { Family }\end{array}$ & $\begin{array}{l}\text { Max. } \\
\text { group: }\end{array}$ & $\begin{array}{l}\text { Abundance in } \\
\text { Max. grp. }\end{array}$ & IV & $\begin{array}{l}P(4999 \\
\text { permutations })\end{array}$ \\
\hline $\begin{array}{l}2009 \text { Pan } \\
\text { trap dipteran } \\
\text { families }\end{array}$ & $\begin{array}{l}\text { Anisopodidae } \\
\text { Carnidae } \\
\text { Chloropidae } \\
\text { Muscidae } \\
\text { Phoridae } \\
\text { Sepsidae } \\
\text { Cecidomiidae } \\
\text { Chironomidae } \\
\text { Culicidae } \\
\text { Tachinidae } \\
\text { Sciomyzidaa }^{\text {a }}\end{array}$ & Infill & $\begin{array}{l}17 \\
931 \\
609 \\
286 \\
510 \\
78 \\
113 \\
421 \\
144 \\
24 \\
23\end{array}$ & $\begin{array}{l}38.5 \\
64.4 \\
73.7 \\
62.6 \\
66.8 \\
62.4 \\
67.7 \\
69.5 \\
71.8 \\
47.9 \\
26.1 \\
\end{array}$ & $\begin{array}{l}0.040 \\
0.017 \\
0.001 \\
0.032 \\
2 \times 10^{-4} \\
0.010 \\
0.003 \\
0.036 \\
0.001 \\
0.015 \\
0.083\end{array}$ \\
\hline $\begin{array}{l}2009 \text { Pan } \\
\text { traps } \\
\text { sciomyzid }\end{array}$ & $\begin{array}{l}\text { No indicators with } \\
\mathrm{P}<0.05 \\
\text { Tetanocera robusta }\end{array}$ & $\begin{array}{l}\text { Infill } \\
\text { Wetland }\end{array}$ & $\begin{array}{l}- \\
82\end{array}$ & $\begin{array}{l}- \\
61.4\end{array}$ & $\begin{array}{l}- \\
0.048\end{array}$ \\
\hline $\begin{array}{l}2010 \text { Pan } \\
\text { traps } \\
\text { sciomyzid }\end{array}$ & $\begin{array}{l}\text { No indicators with } \\
P<0.05 \\
\text { Tetanocera robusta }\end{array}$ & $\begin{array}{l}\text { Infill } \\
\text { Wetland }\end{array}$ & $\begin{array}{l}- \\
12\end{array}$ & $\begin{array}{l}- \\
52.4\end{array}$ & $\begin{array}{l}- \\
0.001\end{array}$ \\
\hline $\begin{array}{l}2010 \text { Sweep } \\
\text { net } \\
\text { sciomyzid }\end{array}$ & $\begin{array}{l}\text { No indicators with } \\
P<0.05 \\
\text { Pherbina coryleti } \\
\text { Ilione albiseta } \\
\text { Tetanocera ferruginea }\end{array}$ & $\begin{array}{l}\text { Infill } \\
\text { Wetland }\end{array}$ & $\begin{array}{l}- \\
41 \\
39 \\
11\end{array}$ & $\begin{array}{l}- \\
- \\
97.6 \\
83.2 \\
80.2\end{array}$ & $\begin{array}{l}- \\
2 \times 10^{-4} \\
8 \times 10^{-4} \\
0.006\end{array}$ \\
\hline
\end{tabular}

${ }^{a}$ Although Sciomyzidae were not a significant indicator family, some sciomyzid species were. 
Two hundred and seven dipteran morphospecies were identified. Site specific factors were the most important factor in accounting for differences among morphospecies (ca. 21\%) based on MRPP analysis of all seven sites (Table 4). The habitat status (i.e. infill versus wetland) accounted for ca. 4\% of morphospecies compositional differences among the data-sets. There were seven significant indicator morphospecies for C\&D waste (within Calliphoridae, Carnidae, Chloropidae, Muscidae, Phoridae and Sepsidae) and nine for wetlands (within Cecidomyiidae, Chironomidae, Lauxaniidae, Psychodidae, Sciaridae and Tachinidae). There was a lack of obvious clustering in the dipteran family and morphospecies NMS ordinations (Fig. $3 b$ and Fig. 3c). This suggested little advantage to using morphospecies, when compared to family data alone. For dipteran family (Fig. 3b) and morphospecies (Fig. 3c) data-sets, soil moisture $\left(\mathrm{r}^{2}=0.298\right)$ and Ellenberg moisture $\left(\mathrm{r}^{2}=0.466\right)$ respectively were strongly correlated with axis 1 (Table 7).

Table 7. Pearsons'correlation coefficients between environmental variables and axes of NMS ordinations a) 2010 plant community data-set, b) 2009 dipteran family data-set, c) 2009 dipteran morphospecies data-set, d) 2010 sciomyzid data-set.

\begin{tabular}{|c|c|c|c|c|c|c|c|c|c|c|}
\hline \multirow{2}{*}{$\begin{array}{l}\text { Data-set } \\
\text { Axis }\end{array}$} & \multicolumn{3}{|c|}{ a) 2010 plants } & \multicolumn{3}{|c|}{$\begin{array}{l}\text { b) } 2009 \text { dipteran } \\
\text { family }\end{array}$} & \multicolumn{3}{|c|}{$\begin{array}{l}\text { c) } 2009 \text { dipteran } \\
\text { morphospecies }\end{array}$} & \multirow{2}{*}{\begin{tabular}{|l|} 
d) 2010 \\
sciomyzid \\
1
\end{tabular}} \\
\hline & 1 & 2 & 3 & 1 & 2 & 3 & 1 & 2 & 3 & \\
\hline Vegetation height & .094 & .033 & .213 & .123 & .201 & .077 & .094 & .032 & .216 & .045 \\
\hline Vegetation length & .104 & .017 & .198 & .118 & .254 & .138 & .103 & .016 & .200 & 205 \\
\hline Ellenberg light & .001 & .006 & .003 & .004 & .018 & .095 & .001 & .007 & .003 & .088 \\
\hline Ellenberg moisture & .466 & .000 & .058 & .288 & .113 & .000 & .466 & .000 & .057 & .043 \\
\hline $\begin{array}{l}\text { Ellenberg reaction } \\
(\mathrm{pH})\end{array}$ & .408 & .001 & .006 & .266 & .010 & .017 & .407 & .002 & .006 & .011 \\
\hline Ellenberg nitrogen & .331 & .000 & .010 & .195 & .000 & .000 & .330 & .000 & .010 & .000 \\
\hline Measured soil pH & .288 & .014 & .005 & .137 & .013 & .020 & .287 & .013 & .006 & .043 \\
\hline $\begin{array}{l}\text { Measured soil } \\
\text { moisture }\end{array}$ & .448 & .000 & .012 & .298 & .004 & .001 & .447 & .000 & .012 & .039 \\
\hline $\begin{array}{l}\text { Measured soil } \\
\text { organic }\end{array}$ & .390 & .004 & .035 & .284 & .004 & .018 & .390 & .003 & .036 & .002 \\
\hline
\end{tabular}

\section{Sciomyzid communities}

There were 192 sciomyzid individuals (seven species) collected using pan traps in 2009 (Fig. 4) and 19 individuals (three species) in 2010 (Fig. 5). Tetanocera robusta Loew accounted for $50 \%(\mathrm{n}=96)$ and $63 \%(\mathrm{n}=12)$ of the total sciomyzid abundances in 2009 and 2010, respectively. This was followed by Tetanocera ferruginea Fallén which represented $43 \%(n=82)$ and $32 \%(n=6)$ of the sciomyzid catches for 2009 and 2010 . In 2009 , ca. $11 \%$ of variation was attributable to site-specific differences, and ca. $7 \%$ of variation could be attributed to habitat status, for pan trap sciomyzid data (Table 4), following MRPP analysis. Tetanocera robusta was found to be a significant indicator species of wetlands in both 2009 and 2010 (Table 6). There were no significant indicator sciomyzid species for infill. A useful NMS ordination could not be constructed from the 2009 sciomyzid data-set due to high variation in abundance data. The 2010 sciomyzid data-set, however, resulted in a 1-dimensional ordination and showed that axis 1 had the strongest correlation $\left(\mathrm{r}^{2}=.205\right)$ with vegetation length (Table 7). 


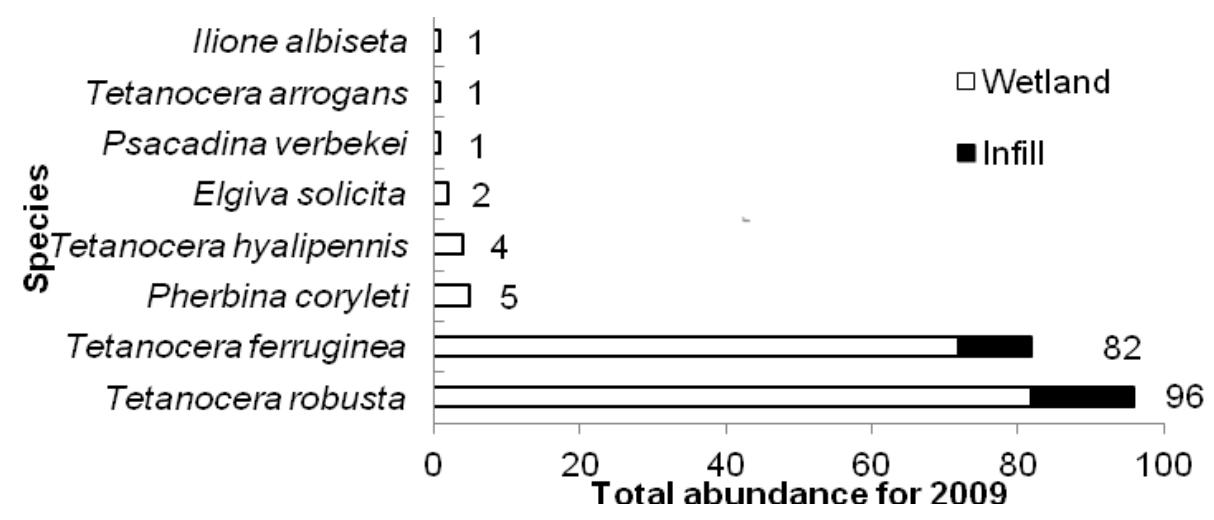

Figure 4. Total sciomyzid species abundances from 2009 (14th July to 13th October) pan trap $(n=54)$ data across all 9 study sites.

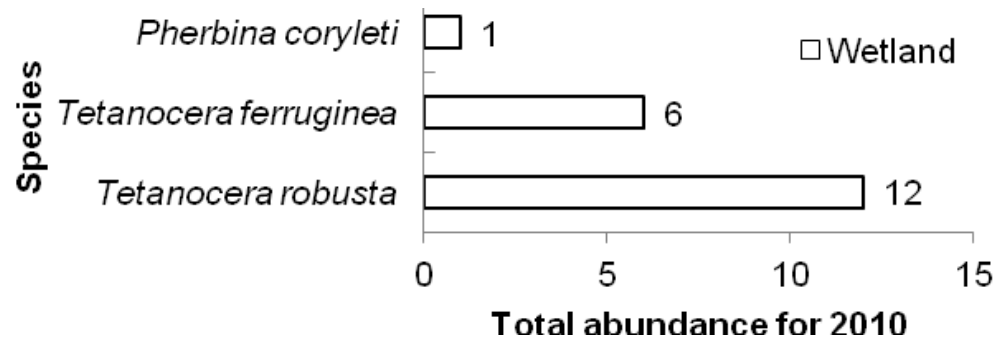

Figure 5. Total sciomyzid species abundances from 2010 (6th May to 30th September) pan traps $(n=42)$ data across 7 study sites.

A total of 110 sciomyzids (12 species) were collected by sweep net in 2010 at WG2 with 105 (11 species) and five individuals (three species) collected on the wetland and infill, respectively (Fig. 5). Of the 12 species collected in total, Pherbina coryleti Scopoli and Ilione albiseta Scopoli were the two dominant species, representing 38\% and $37 \%$ of the total catch, respectively (Fig. 6). The dominant species collected using sweep nets ( $P$. coryleti and I. albiseta) were also different to the dominant species collected with the pan traps ( $T$. robusta and $T$. ferruginea) at the same site (WG2). The 2010 pan trap data (Fig. 4) for WG2 also showed a higher median abundance of sciomyzids on the wetland $(n=5)$ than the infill $(n=0)$. None of the measured environmental variables showed any significant influence on the sweep net results. For the sweep net sciomyzid data, median abundance of all sciomyzid species was significantly greater $(P<0.01)$ on the wetland $(n=9.5)$ than the infill $(n=0)$. Median species richness and median Shannon's entropy were significantly $(P<0.05)$ higher on the wetland than the infill, whereas species evenness was higher on the infill (Table 3). MRPP on the 2010 sciomyzid data (collected using sweep nets on site WG2), showed that ca. $14 \%$ of variation in the data could be attributed to habitat status (Table 4). Although MRPP sometimes indicated a low proportion of explained variance, all tests were highly statistically significant for sciomyzids (Table 4). Indicator species analysis on sciomyzid data from sweep net samples identified three species that were indicative 
of wetlands (Table 6): P. coryleti (97.6\%), I. albiseta (83.2\%) and T. ferruginea $(80.2 \%)$.

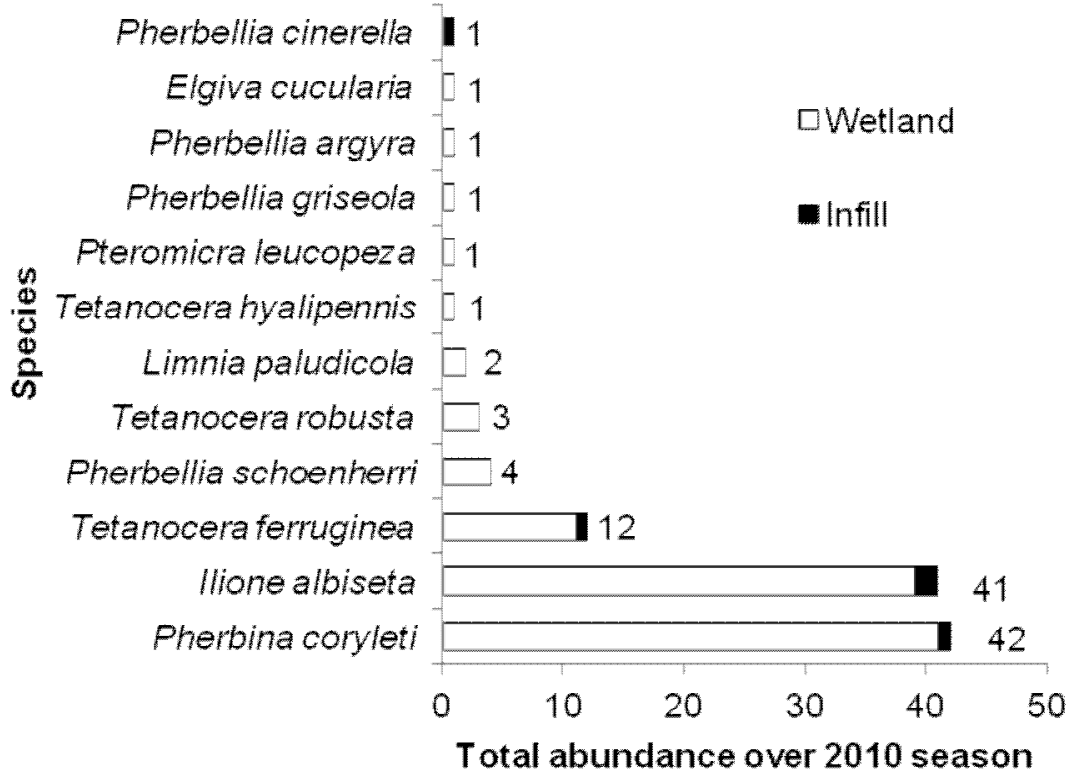

Figure 6. Sciomyzid total abundances (2010 sampling season) for infill and wetland at site WG2 using sweep nets.

\section{Discussion}

\section{Soils and plant communities}

C\&D waste infill substrate on wetlands has significantly different properties $(\mathrm{pH}$, moisture and organic content) in comparison to the non-infilled wetlands and this is likely to be responsible for its impact on plant communities as soil properties (including $\mathrm{pH}$, moisture and nitrogen content) are known to be important factors in their composition (Critchley et al., 2002; Gough et al., 2000; Schultz et al., 2011). In addition, substrate disturbance during the process of infilling likely affects plant communities, allowing ruderal species which have the ability to colonise disturbed ground rapidly, to become more dominant (Grime et al., 1996). In this study indicator species analysis has proven to be a useful tool in identifying the impacts that the soil properties of C\&D waste have on plant communities. Agrostis stolonifera, Cirsium arvense (L.) Scop, Festuca rubra L., Holcus lanatus L., R. repens and Trifolium repens L. are recognised as species associated with areas of moderate disturbance and soils with a higher $(>5) \mathrm{pH}$ (Grime et al., 1996). In this study these were, unsurprisingly, among the most significant indicator species of C\&D waste infill. Molinea caerulea (L.) Moench and Potentilla erecta (L.) Rauschel, both described by Grime et al. (1996) as being positively associated with low $\mathrm{pH}$ soils and undisturbed ground, were significant indicators of acidic wetland areas for this study, having been found extensively on cutover raised bog wetlands. Cladium mariscus (L.), although not a significant wetland indicator species, was the dominant species (Table 2) in site SW1 (wetland only), and is a species found in wet, neutral to alkaline soils $(\mathrm{pH}>6)$, occurring mostly on limestone soils (Conway, 1942), a description befitting this site. As expected there is a strong similarity between the vectors for measured soil properties $(\mathrm{pH}$ and percentage moisture 
content) and estimated values using Ellenberg indices ( $\mathrm{pH}$ and moisture) in the NMS ordinations (Fig. 3 and Table 7).

The disposal of C\&D waste on wetlands significantly increased the plant species Shannon's entropy, but it is important to note that common ruderal species accounted for most of this increase. Based on Grime et al. (1996), some 57\% of all species found on C\&D waste infill in this study are known to have a ruderal strategy compared with just $25 \%$ of species on the wetlands. Given that the ruderal plant species found in this study are common, their replacing of wetland habitat, and all the ecosystem services associated with it (Mitsch and Gosselink, 2007), is less than desirable. When all sites were analysed together, $10 \%$ (Table 4) of the variation in plant communities was attributable to habitat status (infill $v$ wetland). Similarities between infill and wetland are likely due to bare ground, bryophytes, dead vegetation and a small number of species (Epilobium hirsutum L., Juncus effusus L. and Rubus fruticosus L.) which were found to be present in both C\&D infill and wetland quadrats, although not necessarily at the same site, along with the variety of wetland plant communities. This variation can be seen on the NMS ordination (Fig. 3a) where the infill plant communities are more clustered than the plant communities of wetland areas. The points for WG1 are likely to be isolated as the dominant species Elymus repens (L.) was almost exclusively found on that site. Interestingly, the points for the wet grasslands (wetland area) WG1 and WG2 are at almost opposite corners of the ordination, although they classify as the same habitat under Fossitt (2000). This highlights the limitations of using such a broad habitat classification, which takes abiotic factors into account as well as floristic composition. Following separation of sites according to their $\mathrm{pH}$, MRPP shows that plant communities of acidic wetlands are affected to a greater degree (as shown by higher percentage difference attributed to habitat status) than those of alkaline wetlands by the alkaline C\&D waste (Table 4). This was expected as there was a greater difference in $\mathrm{pH}$ between infill and wetland on acidic sites than alkaline sites. Differences between alkaline and acidic site-specific variation could be explained by the variety of alkaline wetland habitats, compared with acidic wetlands.

\section{Dipteran communities}

The impacts of C\&D waste on dipteran communities is less clear than the impacts on plant communities (Fig. 3) where there is less obvious clustering of sites in the NMS ordination. The C\&D waste may have had no significant impact on median dipteran (family and morphospecies) richness, Shannon's entropy and evenness on the infill compared to wetland areas. However, there were significant differences (albeit explaining a low proportion of variance) between community compositions according to the habitat status and among sites. This is likely due to the wide variety of ecological associations within many dipteran families (Keiper et al., 2002; Oosterbroek, 2006). As shown in Table 6, there are a number of dipteran families and morphospecies that were significant bioindicators of both infill (six families and seven morphospecies) and wetland (four families and nine morphospecies). These indicator families changed from generally wetland specialist (Chironomidae, Culicidae), parasitic (Tachinidae), haematophagous (Culicidae) and gall-forming (Cecidomiidae) groups to saprophagous (Anisopodidae, Carnidae, Phoridae, Sepsidae), phytophagous (Chloropidae), haematophagous (Muscidae) and coprophagous (Muscidae, Phoridae) groups, based on published descriptions of the ecology of these families by others (Brake, 2011; Cranston, 1995; McAlpine et al., 1981; Oosterbroek, 2006). 
The loss of aquatic microhabitats in the infill is the most likely cause for the lower abundances of Chironomidae and Culicidae. The change in plant communities is likely to be the cause of the loss of Cecidomiidae and the gaining of Chloropidae as indicator families after infilling. Although Tachinidae can be found in many habitat types, many species may be habitat-specific due to their host species (phytophagous insects such as Lepidoptera) specificity (Stireman III et al., 2006). As a result, their occurrence on the infilled sites may be limited. The family Chironomidae was found to be a significant indicator of wetlands, a finding that is supported elsewhere (Cranston, 1995). The MRPP results also suggest that infilling with C\&D waste may be more detrimental to acidic wetland dipteran communities than those on an alkaline wetland, as higher proportion of variation in dipteran composition can be attributed to habitat status (Table 4) for the dipteran communities of the acidic sites $(6 \%)$ than for alkaline sites $(4 \%)$ regardless of site-specific differences being higher in the latter $(32 \%$ in alkaline sites versus $14 \%$ in acidic sites).

\section{Sciomyzid communities}

Fifty nine species of Sciomyzidae are currently known in Ireland (Speight and Knutson, 2012), 14 of which were collected during this study. The C\&D waste appears to have had a significant impact on sciomyzid communities. Pan trap data showed significant $(P=0.005)$ differences between the sciomyzid communities of the infill and wetland areas even though the distance between the pan traps of each area was only ten metres. Tetanocera robusta was a significant $(P<0.05)$ indicator species for wetlands in both years. Sweep net sampling also showed a significant $(P=0.005)$ difference between infill and wetland, with $P$. coryleti being a significant $(P<0.005)$ indicator species for wetland. These findings support previous studies showing that sciomyzids display limited movement and are habitat specific (Speight, 2004; Vala \& Brunel, 1987; Williams et al., 2009, 2010).

The most dominant species caught using the pan traps (for 2009 and 2010) was $T$. robusta, followed by $T$. ferruginea. The dominance of $I$. albiseta and P. coryleti in the sweep net data when compared with pan traps, supports previous findings (Williams, 2007). At site WG2 sweep nets and pan traps gave very different results. Pan traps collected only $T$. robusta and $T$. ferruginea, whereas the sweep nets collected 12 species. This difference between trapping methods should be considered if using sciomyzids as bioindicators. The significant wetland indicator sciomyzid species $(T$. robusta and $P$. coryleti) are known to prey and feed on multiple aquatic snail species from several genera as larvae (Speight and Knutson, 2012) as are all sciomyzids found on C\&D waste (with the exception of Pherbellia cinerella Fallén which preys upon a range of terrestrial and semi aquatic gastropods). Interestingly, although these aquatic snails usually prefer alkaline water and the C\&D waste is more alkaline than the wetlands, there was a decrease in the abundance of sciomyzids collected on the C\&D waste. This was likely due to a shortage of appropriate aquatic microhabitats on the $\mathrm{C} \& \mathrm{D}$ waste for the aquatic snails and sciomyzid larvae.

Pherbellia cinerella was the only species to have been collected (one individual with sweep net) solely on the C\&D waste infill. This was not surprising given its known occurrence on dry habitats (Speight and Knutson, 2012). All of the other sciomyzid species collected are associated almost exclusively with 'wet' habitats (Speight and Knutson, 2012). The observation here that these species were all either exclusively found on wetlands, or had a large majority on the wetlands, highlights their sedentary 
nature and usefulness as bioindicators of wetland habitat change. The low number of sciomyzid individuals collected is a trait of the family which is not unknown, although there are some species (such as I. albiseta) that are often found in high numbers (Williams et al., 2009; Williams et al., 2010).

\section{Problems encountered}

From the start of this study, it was found that wetlands were often perceived by landowners as valueless land, especially if peat had already been cut away from bogs, or if they were too wet to graze with livestock. Landowners sought to improve the land by covering the infill with topsoil to produce agriculturally productive grasslands. Permits specifically for the disposal of C\&D waste have been available from local authorities in Ireland since 2001.

The almost complete absence of published information on ecological impacts of infilling wetlands with C\&D waste is not aided by the problems associated with studying these sites. Permission to undertake ecological work has to be obtained from the landowner and this permission is likely to be refused at any time given the nature of the activity, as happened on site SW2 at the start of year two. The disturbance of sites by heavy machinery and the process of infilling had been anticipated as a potential problem at the beginning of the study, but this is very difficult to predict as sites that appear 'dormant' can become active at any time (as happened with site CB5 at the beginning of year two), depending on the volume of waste being produced in the locality. Two more otherwise suitable sites had to be removed from the study at the beginning of Year 1 (in addition to the loss of individual samples from several sites over the study) as a result of human interference with equipment being stolen and broken repeatedly. As these (usually poorly fenced) sites were frequently located near ruralurban interfaces and major roads, they were highly visible to members of the public. Shortly after our studies commenced at some of the sites, sampling was compromised by members of the public moving or emptying traps and/or flattening vegetation and non-permissible waste items were observed on more than one occasion. There were also unforeseen restrictions regarding invertebrate sampling, in particular, the limitations of using sweep nets caused by the hazardous topography of infilled sites.

Currently, some inspections of waste composition at C\&D waste sites are carried out by the local authority but daily inspections of waste are the responsibility of the waste haulier and landowner. Although the waste permits were almost always granted to landowners with the condition of using the land for agricultural purposes afterwards, it was frequently found in this study (particularly for sites owned by building developers) that these sites were left without topsoil or had been further developed (residential or commercial buildings or yards). There is a possibility that this type of permit could provide a route for such surreptitious development of wetland areas, for which it would be difficult to get permission directly.

\section{Recommendations}

Our results indicate that the infilling of wetlands in this study with C\&D waste has resulted primarily in the replacement of wetland plant communities with ruderal plant species and a reduction in wetland specialist Diptera. Given these dramatic changes, it is likely that the wetland ecosystem function of the sites studied has been impaired. However, the degree and significance of impairment will depend on the resilience of the 
wetland which in turn depends, inter alia, on the wetland type, the size of the wetland, its connectivity with other wetlands and the proportion of the wetland infilled with C\&D waste. While it could be argued that any loss in wetland ecosystem function should be avoided at all costs, the reality is that, in the absence of complete C\&D waste recycling, wetlands, particularly those not included in Natura 2000, will continue to be infilled for the foreseeable future. With this in mind, we would make the following recommendations:

- All future waste permits (regardless of site size or C\&D tonnage) should require either an independent Environmental Impact Assessment or an Appropriate Assessment. These assessments should include, as a minimum, surveys of plants, wetland invertebrate assemblages and wetland vertebrates in addition to the collection of physical data on soils and hydrology. If permission is granted, these surveys will provide baseline data for future monitoring of the sites.

- Annual ecological surveys should be undertaken by local authorities or a third party authorised by them, to monitor changes in the wetlands after infilling has commenced and to ensure that licensing agreements are adhered to.

- Invertebrate baseline monitoring stations, protected by security fencing to avoid damage by vandalism, should be set up (prior to and during infilling). Once these secure stations are in place, more visible invertebrate sampling methods such as malaise, emergence and pitfall traps could be employed.

- The above increased ecological monitoring could contribute to a database used to inform decisions regarding appropriate site selection for C\&D infilling, thereby preserving those wetlands which are most vulnerable.

- At least part of the wetland sites used for C\&D infill should be protected from future infilling activities. The initial ecological assessment could be used to determine the most ecologically valuable area to protect.

\section{Conclusions}

The infilling of wetlands in this study with C\&D waste has had an impact on soil properties and plant communities. Dipteran communities were also affected by the C\&D waste infill, probably as a result of the changes in plant communities and the loss of 'wet' areas. There are many potential problems with carrying out such studies and recommendations have been given to overcome these. Given the paucity of research in this area, this study highlights that the infilling of wetlands with C\&D waste can have serious consequences for wetland ecology.

Future research should focus on C\&D waste infill sites of different waste composition and in areas of different geographical, geological, topographical and meteorological settings. Following further research, this information could be used by planning authorities to aid in future policy making and in the development of sustainable C\&D waste management strategies.

Acknowledgements. This study was funded by the National University of Ireland Galway, Millennium Fund. Special thanks to Owen Doherty, David Clarke, Marie-Louise Vauthier, Kevin Mc Affrey, Maurice Martin, Alban Modiere, Elaine Williams, Lloyd Knutson, Jean-Claude Vala, John Frawley and the cooperative landowners. 


\section{REFERENCES}

[1] Beattie, A.J., Oliver, I. (1994): Taxonomic minimalism. - TREE 9: 488-490.

[2] Brake, I. (2011): World Catalogue of the Family Carnidae (Diptera, Schizophora). - Myia 12: 113-169.

[3] BSI. (1990): BS 1377: Part 2 - Soils for civil engineering purposes classification tests. BS 1377 series. - British Standards Institution, London.

[4] Bullock, J.M. (2006) Plants. - In: Sutherland, W.J. (ed) Ecological Census Techniques. Second edition. Cambridge University Press, UK.

[5] CAAS Environmental Services Ltd. (2003): Advice notes on current practice. - Prepared for The Environmental Protection Agency, Ireland.

[6] Campbell, J.W., Hanula, J.L. (2007): Efficiency of Malaise traps and colored pan traps for collecting flower visiting insects from three forested ecosystems. - Journal of Insect Conservation 11: 399-408.

[7] Cardoso, P., Irwin, T.L., Borges, P.A.V., New, T.R. (2011): The seven impediments in invertebrate conservation. - Biological Conservation 144: 2647-2655.

[8] Chen, X., Bain, M., Sullivan, P.J., Wang, Z. (2012): Wetland Loss and Research Orientation. - Challenges 3(1): 43-48.

[9] Cheptou, P.O., Carrue, O., Rouifed, S., Cantarel, A. (2008): Rapid evolution of seed dispersal in an urban environment in the weed Crepis sancta. - Proceedings of the National Academy of Sciences USA 105: 3796-3799.

[10] Cochran, K., Townsend, T., Reinhart, D., Heck, H. (2007): Estimation of regional building-related C\&D debris generation and composition: Case study for Florida, US. Waste Management 27: 921-931.

[11] Conway, V.M. (1942): Cladium P. Br.. - Journal of Ecology 30: 211-216.

[12] Costanza, R., d'Arge, R., de Groot, R., Farber, S., Grasso, M., Hannon, B., Limburg, K., Naeem, S., O’Neill, R.V., Paruelo, J., Raskin, R.V., Sutton, G., Van den Belt, M. (1997): The value of the world's ecosystem services and natural capital. - Nature 387: 253-260.

[13] Cranston, P.S. (1995): Introduction. - In: Armitage, P., Cranston, P.S., Pinder, L.C.V. (eds.) The Chironomidae: The biology and ecology of non-biting midges. Chapman \& Hall, London.

[14] Critchley, C.N.R., Chambers, B.J., Fowbert, J.A., Sanderson, R.A., Bhogal, A., Rose, S.C. (2002): Association between lowland grassland plant communities and soil properties. - Biological Conservation 105: 199-215.

[15] Dufrêne, M., Legendre, P. (1997): Species assemblages and indicator species: The need for a flexible and asymmetrical approach. - Ecological Monographs 67: 345-366.

[16] EC. (1995): Commission communication to the Council and the European Parliament: Wise use and conservation of wetlands. - European Commission, Brussels.

[17] EPA. (1996): National Waste Database Report for 1995. - Environmental Protection Agency, Ireland.

[18] EPA. (2002): European Waste Catalogue (EWC) and Hazardous waste list 2002. Environmental Protection Agency, Ireland.

[19] EPA. (2009): National Waste Database Report 2007. - Environmental Protection Agency, Ireland.

[20] EPA. (2008): Waste Facility Permit \& Certificate of Registration application form. Environmental Protection agency, Ireland.

[21] European Commission DG ENV (2002): Assessment of plans and projects significantly affecting Natura 2000 sites; Methodological guidance on the provisions of articles 6 (3) and (4) of the Habitats Directive 92/43/EEC. - European Commission, Brussels.

[22] European Commission DG ENV (2011): Service Contract on Management of Construction and Demolition waste - SR1. Final Report Task 2. - European Commission, Brussels. 
[23] Eurostat. (2011): Eurostat Yearbook 2011: Environment. - The Publications Office of the European Union, Luxembourg.

[24] Fischer, C., Werge, M. (2009): EU as a Recycling Society: present recycling levels of municipal waste and construction and demolition waste in the EU. - European Topic Centre on Sustainable Consumption and Production, Copenhagen.

[25] Fossit, J.A. (2000): A guide to Habitats in Ireland. The Heritage Council, Kilkenny.

[26] Gabrey, S.W. (1997): Bird and small mammal abundance at four types of wastemanagement facilities in northeast Ohio. - Landscape and Urban Planning 37: 223-233.

[27] Gough, L., Shaver, G.L., Carroll, J., Royer, D.L., Laundre, J.A. (2000): Vascular plant species richness in Alaskan arctic tundra: the importance of soil pH. - Journal of Ecology 88: 54-66.

[28] Grime, J.P., Hodgson, J.G., Hunt, R. (1996): Comparative Plant Ecology. A Functional Approach to Common British Species. - Chapman and Hall, London.

[29] Hill, M.O., Mountford, J.O., Roy, D.B., Bunce, R.G.H. (1999): ECOFACT 2a Technical Annex - Ellenberg's indicator values for British plants. - In: Bunce, R.G.H., Smart, S.M., van de Poll, H.M., Watkins, J.W., Scott, W.A., (eds.) ECOFACT 2: Measuring Change in British Vegetation. Vol. 2a. Her Majesty's Stationary Office, Huntington.

[30] Hill, M.O., Roy, D.B., Mountford, J.O., Bunce, R.G.H. (2000): Extending Ellenberg's indicator values to a new area: an algorithmic approach. - Journal of Applied Ecology 37: 3-15.

[31] Hughes, J.B., Daily, G.C., Ehrlich, P.R. (2000): Conservation of Insect Diversity: a Habitat Approach. - Conservation Biology 14: 1788-1797.

[32] Jost, L. (2006): Entropy and diversity. - OIKOS 113: 363-375.

[33] Keddy, P.A. (2000): Wetland Ecology principles and conservation. - University Press, Cambridge.

[34] Keiper, J.B., Walton, W.B., Foote, B.A. (2002): Biology and Ecology of Higher Diptera from Freshwater Wetlands. - Annual Review of Entomology 47: 207-232.

[35] Kenkel, N.C., Orloci, L. (1986): Applying metric and nonmetric multidimensional scaling to ecological studies: some new results. - Ecology 67(4): 919-928.

[36] King, R.S., Brazner, J.C. (1999): Coastal wetland insect communities along a trophic gradient in Green Bay, Lake Michigan. - Wetlands 19: 426-437.

[37] Knutson, L.V., Vala, J.C. (2011): Biology of Snail-killing Sciomyzidae Flies. University Press, Cambridge.

[38] Krause, J.R., Bertrand, K.N., Kafle, A., Troelstrup, Jr. N.H. (2013): A fish index of biotic integrity for South Dakota's Northern Glaciated Plains Ecoregion. - Ecological Indicators 34: 313-322.

[39] LaPaix, R., Freedman, B., Patriquin, D. (2009): Ground vegetation as an indicator of ecological integrity. - Environmental Reviews 17: 249-265.

[40] Lehner, B., Döll, P. (2004): Development and validation of a global database of lakes, reservoirs and wetlands. - Journal of Hydrology 296(1-4): 1-22.

[41] McAlpine, J.F., Peterson, B.V., Shewell, G.E., Teskey, H.J., Vockeroth, J.R., Wood, D.M. (1981): Manual of Nearctic Diptera Volume 1. - Canadian Government Publishing Centre, Hull.

[42] McCune, B., Grace, J.B. (2002): Analysis of ecological communities. - MjM Software Design, Gleneden Beach.

[43] McCune, B., Mefford, M.J. (1999): PC-ORD. Multivariate Analysis of Ecological Data. MjM Software Design, Gleneden Beach.

[44] McGeouch, M.A. (1998): The selection, testing and application of terrestrial insects as bioindicators. - Biological Reviews 73: 181-201.

[45] Meilke, P., Berry, P. (2001): Permutation Methods: A Distance Function Approach. Springer, New York.

[46] Mitsch, W.J., Gosselink, J.G. (2007): Wetlands. $4^{\text {th }}$ ed. - Wiley, New Jersey. 
[47] Murphy, W.L., Knutson, L.V., Chapman, E.G., Mc Donnell, R.J., Williams, C.D., Foote, B.A., Vala, J.C. (2012): Key aspect of the biology of snail-killing Sciomyzidae flies. Annual Review of Entomology 57: 425-447.

[48] OEE (2008): Guidance Manual: Waste Facility Permit and Registration Regulations. Office of Environmental Enforcement, Environmental Protection Agency, Ireland.

[49] Oosterbroek, P. (2006): The European Families of the Diptera. Identification, Diagnosis and Biology. - KNNV Publishing, Utrecht.

[50] Pardo, L.H., Fenn, M.E., Goodale, C.L., Geiser, L.H., Driscoll, C.T., Allen, E.B., Baron, J.S., Bobbink, R., Bowman, W.D., Clark, C.M., Emmett, B., Gilliam, F.S., Greaver, T., Hall, S.J., Lilleskov, E.A., Liu, L., Lynch, J., Nadelhoffer, K., Perakis, S.S., RobinAbbott, M.J., Stoddard, J., Weathers, K., Dennis, R.L. (2011): Effects of nitrogen deposition and empirical nitrogen critical loads for ecoregions of the United States. Ecological Applications 21: 3049-3082.

[51] Poon, C.S., Yu, A.T.W., Ng, L.H. (2001): On-site sorting of construction and demolition waste in Hong Kong. - Conservation and Recycling 32: 157-172.

[52] Rivers-Moore, N.A., Samways, N.J. (1996): Game and cattle trampling, and impacts of human dwellings on arthropods at a game park boundary. - Biodiversity and Conservation 5: $1545-1556$.

[53] Rose, F., O'Reilly, C. (2006): The Wild Flower Key: How to identify wild flowers, trees and shrubs in Britain and Ireland. Revised expanded edition. - Penguin Books Ltd., London.

[54] Rozkošný, R. (1984): The Sciomyzidae (Diptera) of Fennoscandia and Denmark. Fauna Entomologica Scandinavica, Vol. 14. - Scandinavian Science Press Ltd., LeidenCopenhagen.

[55] Rozkošný, R. (1987): A Review of the Palaearctic Sciomyzidae (Diptera). - Folia Facultatis Scientiarum Naturalium Universitatis Purkynianae Brunensis Biologia 86:1156.

[56] Schultz, R., Andrews, S., O'Reilly, L., Bouchard, V., Frey, S. (2011): Plant Community Composition More Predictive than Diversity of Carbon Cycling in Freshwater Wetlands. - Wetlands 31: 965-977.

[57] Shen, L.Y., Tam, V.W.Y., Tam, C.M., Drew, D. (2004): Mapping approach for examining waste management on construction sites. - Journal of Construction Engineering and Management (ASCE) 130(4): 472-481.

[58] Statutory Instrument No. 165/1998 (1998): Waste Management (Permit) Regulations, 1998. - Government of Ireland. Available via: www.irishstatutebook.ie/1998/en/si/0165.html Accessed 6th September, 2013.

[59] Statutory Instrument No. 821 of 2007 (2007): Waste Management (Facility Permit and Registration) Regulations 2007. - Government of Ireland. Available via: www.irishstatutebook.ie/2007/en/si/0821.html Accessed 6th September, 2013.

[60] Southwood, T.R.E. (1978): Ecological Methods with particular reference to the study of insect populations. - Chapman and Hall, London.

[61] Speight, M.C.D. (1986): Criteria for the selection of insects to be used as bioindicators in nature conservation research. - In: Velthius, H.H.W. (ed.) Proceedings of $3^{\text {rd }}$ European Congress of Entomology. Amsterdam.

[62] Speight, M.C.D. (2004): Predicting impacts of change in farm management on sciomyzids (Diptera: Sciomyzidae): a biodiversity case study from southern Ireland. Dipterists digest 11: 147-166.

[63] Speight, M.C.D., Knutson, L.V. (2012): Species accounts for Sciomyzidae and Phaeomyiidae (Diptera) known from the Atlantic zone of Europe. - Dipterists Digest 19: $1-38$.

[64] Stireman, III, J.O., O’Hara, J.E., Wood, D.M. (2006): Tachinidae: Evolution, Behaviour and Ecology. - Annual Review of Entomology 51: 525-555.

[65] Unwin, D.M. (1984): A key to the families of British Diptera. Field Studies Council, UK. 
[66] USEPA. (2009): Estimating 2003 Building Related Construction and Demolition Materials Amounts. - U.S. Environmental Protection Agency, Washington.

[67] Vala, J.C., Brunel, C. (1987): Diptères Sciomyzides capturés dans le département de la Somme. - Bulletin mensuel de la Société Linnéenne de Lyon 56: 187-191.

[68] Webb, D.A., Parnell, J., Doogue, D. (1996): An Irish Flora. $7^{\text {th }}$ ed. Dundalgan Press, Dundalk.

[69] Whiles, M.R., Goldowitz, B.S. (2001): Hydrologic Influences on Insect Emergence Production from Central Platte River Wetlands. - Ecological Applications 11(6):18291842.

[70] Williams, C.D. (2007): The Environmental requirements of Sciomyzidae (Diptera) with particular reference to the role of Mollusc host/prey communities [PhD dissertation]. National University of Ireland, Galway.

[71] Williams, C.D., Moran, J., Doherty, O., Mc Donnell, R.J., Gormally, M.J., Knutson, L.V., Vala, J.C. (2009): Factors affecting Sciomyzidae (Diptera) across a transect at Skealoghan Turlough (Co. Mayo, Ireland). - Aquatic Ecology 43: 117-133.

[72] Williams, C.D., Gormally, M.J., Knutson, L.V. (2010): Very high population estimates and limited movement of snail-killing flies (Diptera: Sciomyzidae) on an Irish turlough (temporary lake). - Biology and Environment: Proceedings of the Royal Irish Academy 110B: 81-94.

[73] Williams, C.D., Beltman, B., Moran, J., Sheehy-Skeffington, M., Gormally, M.J. (2011): Empirical support for the possible application of modified Ellenberg indices to the study of environmental gradients on dynamic Irish wetlands - evidence from Skealoghan turlough, County Mayo. - Biology and Environment: Proceedings of the Royal Irish Academy 111B: 1-13.

[74] Williams, P.T. (1998): Waste Treatment and Disposal. - Wiley, UK. 